\title{
PENYULUHAN MENCUCI TANGAN YANG BENAR PERAWATAN GIGI DAN KUKU DI TK GUGUS TENAYAN RAYA PEKANBARU
}

\author{
Berliana Irianti, S.Si.T, M.Keb ${ }^{(1)}$, Nur Israyati( ${ }^{(2)}$, Putri Marissa ${ }^{(3)}$ \\ STIKes Hang Tuah Pekanbaru \\ berlianairianti@htp.ac.id
}

\begin{abstract}
ABSTRAK
Hand washing behavior is a trivial matter. So trivial that many people ignore it, even though the behavior of washing hands can prevent various types of diseases.

The maintenance of personal hygiene greatly determines the health status, where individuals consciously and on personal initiative maintain health and prevent disease. This effort is more profitable for individuals because it saves more money, effort and time in realizing welfare and health. Personal hygiene maintenance efforts include cleanliness of hair, eyes, ears, teeth, mouth, skin, nails, and hygiene in clothing.

The untreated condition of the mouth and teeth gives the bacteria in the mouth the freedom to multiply, allowing gum disease and tooth decay to occur.

Caring for nails is an important aspect of maintaining self-care because various germs can enter the body through the nails in addition to washing hands with soap and running water.

Based on the survey conducted, there were still many problems in the family regarding the importance of performing hygiene hygiene for pre-school children at the TK Gugus Tenayan Raya. Therefore, it needs to be overcome by holding counseling on personal hygiene.
\end{abstract}

Keywords: hand hygiene, oral teeth and nails

\section{ABSTRAK}

Perilaku mencuci tangan adalah masalah sepele. Begitu sepelenya hingga banyak orang mengabaikannya, padahal perilaku mencuci tangan mampu mencegah berbagai jenis penyakit. Pemeliharaan kebersihan diri sangat menentukan status kesehatan, di mana individu secara sadar dan atas inisiatif pribadi menjaga kesehatan dan mencegah terjadinya penyakit. Upaya ini lebih menguntungkan bagi individu karena lebih hemat biaya, tenaga dan waktu dalam mewujudkan kesejahteraan dan kesehatan. Upaya pemeliharaan kebersihan diri mencakup tentang kebersihan rambut, mata, telinga, gigi, mulut, kulit, kuku, serta kebersihan dalam berpakaian.

Keadaan mulut dan gigi yang tidak terawat memberikan bakteri di dalam mulut keleluasaan untuk berkembang biak, sehingga memungkinkan terjadinya penyakit gusi dan kerusakan gigi. Merawat kuku merupakan salah satu aspek penting dalam mempertahankan perawatan diri karena berbagai kuman dapat masuk kedalam tubuh melalui kuku selain mencuci tangan dengan sabun dan air mengalir.

Berdasarkan survey yang dilakukan masih banyak ditemukan masalah dalam keluarga tentang pentingnya melakukan kebersihan hygiene pada anak-anak pra sekolah diTK Gugus Tenayan Raya. Maka dari itu, perlu diatasi dengan diadakannya penyuluhan tentang kebersihan diri.

Kata Kunci: kebersihan Tangan, Gigi mulut dan Kuku 


\section{PENDAHULUAN}

Perilaku mencuci tangan adalah masalah sepele. Begitu sepelenya hingga banyak orang mengabaikannya, padahal perilaku mencuci tangan mampu mencegah berbagai jenis penyakit. Perserikatan Bangsa-Bangsa menetapkan 15 Oktober sebagai Hari Cuci Tangan Pakai Sabun (HCTPS). Penetapan HCTPS sekaligus merupakan kampanye dalam rangka menggalakkan perilaku mencuci tangan dengan sabun oleh masyarakat sebagai upaya untuk menurunkan tingkat kematian balita dan pencegahan terhadap penyakit yang dapat berdampak pada penurunan kualitas hidup manusia.

Mencuci tangan dengan sabun mengurangi angka infeksi saluran pernapasan dengan dua langkah: pertama, melepaskan patogen-patogen pernapasan yang terdapat pada tangan dan permukaan telapak tangan dan, kedua, menghilangkan patogen (kuman penyakit) lainnya (terutama virus entrentic) yang menjadi penyebab tidak hanya diare namun juga gejala penyakit pernapasan lainnya.

Pemeliharaan kebersihan diri sangat menentukan status kesehatan, di mana individu secara sadar dan atas inisiatif pribadi menjaga kesehatan dan mencegah terjadinya penyakit. Upaya ini lebih menguntungkan bagi individu karena lebih hemat biaya, tenaga dan waktu dalam mewujudkan kesejahteraan dan kesehatan. Upaya pemeliharaan kebersihan diri mencakup tentang kebersihan rambut, mata, telinga, gigi, mulut, kulit, kuku, serta kebersihan dalam berpakaian.

Keadaan mulut dan gigi yang tidak terawat memberikan bakteri di dalam mulut keleluasaan untuk berkembang biak, sehingga memungkinkan terjadinya penyakit gusi dan kerusakan gigi. Selain itu, efek samping obat-obatan, seperti antihistamin, pereda nyeri, dan dekongestan, dapat menyebabkan berkurangnya produksi air liur, yang turut berkontribusi terhadap perkembangbiakan bakteri.

Merawat kuku merupakan salah satu aspek penting dalam mempertahankan perawatan diri karena berbagai kuman dapat masuk kedalam tubuh melalui kuku selain mencuci tangan dengan sabun dan air mengalir. Oleh sebab itu, kuku seharusnya tetap dalam keadaan sehat dan bersih. Kuku terdapat di ujung jari bagian yang melekat pada kulit yang terdiri dari selsel yang masih hidup. Kuku jari tangan maupun kuku jari kaki harus selalu 
terjaga kebersihannya karena kuku yang kotor dapat menjadi sarang kuman penyakit yang selanjutnya akan ditularkan kebagian tubuh yang lain Dan perawatan kuku juga mempengaruhi pertumbuhan kuku.

\section{METODE KEGIATAN}

Metode pengabdian masyarakat ini dilaksanakan dalam bentuk penyuluhan dan pelaksanaan Mencuci Tangan Yang Benar, menggosok gigi dan memotong kuku dengan memberikan ceramah langsung, leaflet berisi materi dan gambar yang menarik.

\section{HASIL DAN PEMBAHASAN}

\section{Hasil Pelaksanaan}

Kegiatan yang dilakukan dalam pengabdian kepada masyarakat ini dilaksanakan dalam beberapa tahapan yang diawali dengan pemberian penyuluhan terlebih dahulu tentang pentingnya kebersihan diri pada anak TK, kebersihan gigi dan mulut, mencuci tangan yang benar dan memotong kuku.

Kegiatan sosialisasi Pada anak TK ini telah dilaksanakan pada bulan Februari 2019 pada anak pra sekolah. Berdasarkan pengamatan selama kegiatan berlangsung, kegiatan pengabdian pada masyarakat ini memberikan hasil sebagai berikut : $\square \quad$ Meningkatnya pengetahuan dan pemahaman anak-anak pra sekolah karena kurangnya informasi atau pengetahuan. Hal ini dilihat dari kemampuan anak-anak prasekolah yang mampu menjawab pertanyaanpertanyaan yang diberikan.
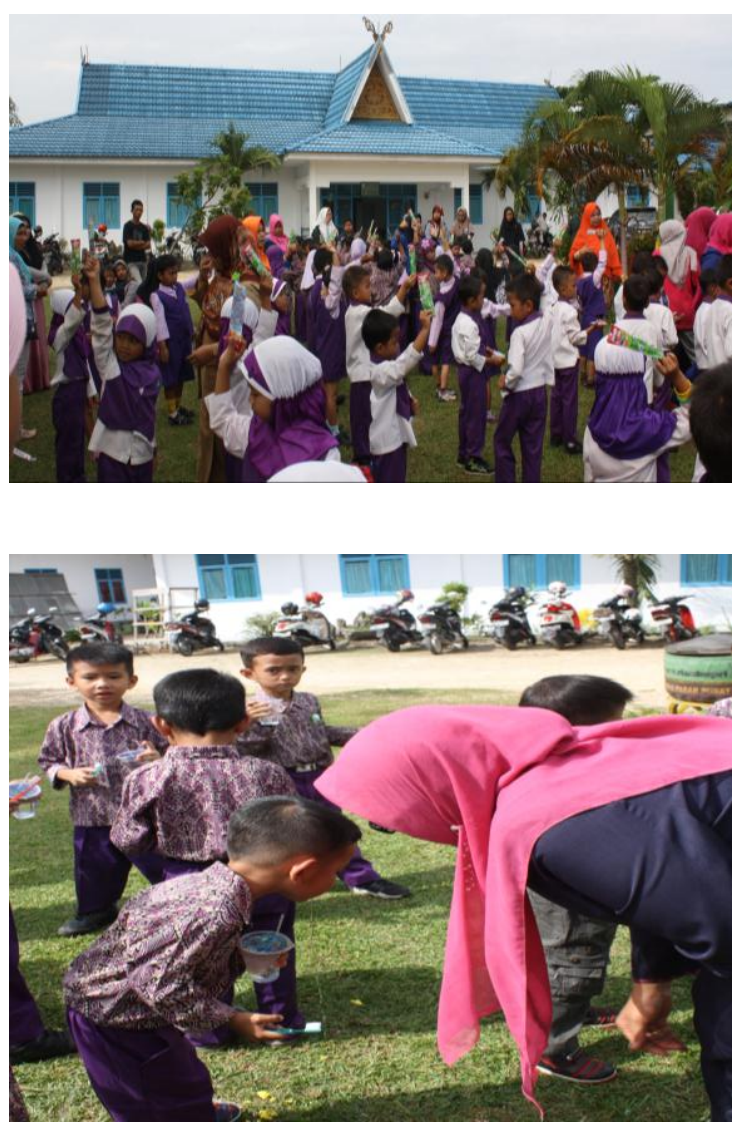

\section{Pembahasan}

Kegiatan penyuluhan tentang hygiene pada anak pra sekolah di TK Gugus Tenayan Raya berjalan dengan sangat baik. Hal ini terlihat dari antusias nya para anak-anak TK yang hadir pada saat kegiatan berlangsung, banyak anakanak TK yang bertanya menunjukkan rasa ingin tahu mereka terhadap materi yang disampaikan. 
Untuk menjaga kesehatan gigi dan mulut dengan efektif, Anda juga bisa menggunakan obat kumur atau mouthwash. Menjaga kesehatan gigi dan mulut sebenarnya tidak sulit karena Anda dapat melakukannya sendiri di rumah. Yang terpenting adalah tetap konsisten dan menjadikannya sebagai bagian dari rutinitas. Peserta diajak menghafal lagu dan gerakan langkah-langkah mencuci tangan sebagai berikut :

1. Telapak dengan telapak

2. Telapak kanan diatas punggung tangan kiri dan telapak kiri diatas punggung tangan kanan

3. Telapak dengan telapak dan jari saling terkait

4. Letakan punggung jari pada telapak satunya dengan jari saling menguncup

5. Jempol kanan digosok memutar oleh telapak kiri dan sebaliknya

6. Jari kiri menguncup, gosok memutar ke kanan dan ke kiri pada telapak tangan dan sebaliknya

7. Pegang pergelangan tangan kiri dan tangan kanan dan sebaliknya, gerakan memutar

\section{KESIMPULAN}

1. Pengetahuan anak pra sekolah TK Gugus Tenayan Raya sudah cukup baik, hal ini terlihat dari respon audience pada saat dilakukan Tanya jawab tentang materi penyuluhan dan memberikan pertanyaan

2. Keterlibatan anak-anak prasekolah dalam mencuci tangan yang benar, perawatan gigi, erta perawatan kuku cukup baik, pada saat dilakukan demonstrasi semua anak-anak pra sekolah ikut serta dan antusia memperhatikan dan mengikuti yang didemonstrasikan.

\section{DAFTAR PUSTAKA}

Lorna Fewtrell, Kaufmann R.B., Kay D., Enanoria W., Haller L., dan Colford J.M.C., Jr 2005. "Water, sanitation, and hygiene interventions to reduce diarrhoea in less developed countries: A systematic review and meta analysis." The Kancet Infectious Diseases, Vol. 5, Issue 1:42-52.

Curtis, V. and Cairncross, S. 2003. "Effect of washing hands with soap on diarrhoea risk in the community: A systematic review." The Lancet Infetious Diseases, Vol.3, May 2003, pp 275-281.

APIC Guidelines for handwashing and hand antisepsis in health care settings American Journal of Infection Control. 1995;23:251-269 
A.Poter, Patricia, Pery, 2002, Mosby: Elsevier Science.

Ketrampilan dan Prosedur Dasar, 